\title{
Caring for a parent while working for pay in the German welfare regime
}

\author{
By Wolfgang Keck* $\mathcal{E}$ Chiara Saraceno*
}

\begin{abstract}
This article presents the results of a study that addresses the strategies adopted by adult children in employment who bear the main care responsibility for a frail parent. The context of the study is the resources and constraints offered and imposed, respectively, by long-term care policies in Germany. The empirical part is based on 34 in-depth interviews conducted in winter 2007-2008 in Berlin and Brandenburg. Five different care arrangements emerge at the interfaces of family resources and constraints, paid work demands, other family demands and policy options. These represent different ways of dealing with the interference that can occur between work and care, and other dimensions of personal and family life. In the conclusion, against the background of the research findings, the authors discuss the role of the German policy framework for long-term care in terms of its efficacy in providing adequate care and in easing work-family tensions in a context characterised by unequal private resources.
\end{abstract}

Keywords: ageing, care, work-family conciliation, social policies.

*Wolfgang Keck and Chiara Saraceno, Social Science Research Center Berlin (WZB), Berlin, Germany. 
International Journal of Ageing and Later Life

\section{Premise}

The combination of population ageing, rising women's labour force participation and changes in the statutory retirement age for both men and women means a growing number of workers must find ways to reconcile care responsibilities with their job demands (Lechner 1999; for Germany, see Blinkert \& Klie 2001; Häcker \& Raffelhüschen 2007). The later phase of working life is thus increasingly characterised by workfamily conciliation issues, which are no longer limited to the child-rearing years. In Germany, according to the 2005 Labour Force Survey, 4\% of the working population aged 15-65 has some care responsibility for an adult relative or friend. The carers are strongly concentrated in the 45-54 age bracket, where they comprise $7 \%$ of workers. Women are over-represented both in the working and the non-working population of carers. However, about $40 \%$ of those in employment who have some care responsibility for an adult are men (see Schupp \& Künemund 2004).

As in the case of small children, policies addressing both the care needs of dependent adults and the responsibilities and needs of family carers play a crucial role in the way individuals and families deal with the care requirements of a dependent family member. In fact, the options they offer, the degree of time coverage they grant and the quality of the care they provide all shape the framework of constraints and resources within which individuals decide to take on care responsibilities and structure their care arrangements, fitting them in with their work and other family obligations.

This article presents the results of a study that, within the specific context of the resources provided and the constraints imposed by German long-term care policies, addresses the strategies and needs of adult children who are both in employment and bear the main responsibility for the care of a frail old parent (or parent-in-law). The study is part of a larger comparative project examining resources, tensions and stresses in work-care arrangements among the parents of young children and the adult children of disabled or very frail parents in different policy settings. ${ }^{1}$

${ }^{1}$ The Workers Under Pressure and Social Care (WOUPS) project, financed by the French ANR and MIRE. It includes France, Germany, Italy, Portugal, Sweden and the Netherlands. 
Following an overview of the literature and the presentation of our theoretical framework, the article outlines those characteristics of German long-term care insurance that are relevant for family carers who are also in paid work. On the basis of 34 in-depth interviews conducted in winter 2007-2008, it then describes the different strategies of family carers as they are developed at the interface of policy options, family resources and constraints, and the demands of paid work. It focuses in particular on patterns of care packaging and on the role these have in the way carers deal with the interference and tensions that arise between working, caring for a parent, and their own personal and family life. In the conclusion, against the background of the research findings, the role of Germany's policy framework for long-term care is discussed with respect to its adequacy in providing satisfactory care and in easing work-family tensions in a context marked by inequalities in private resources.

\section{Literature Review and Theoretical Framework}

According to the literature, at least five analytically distinct aspects are important in considering interference between care obligations and being in employment (Cullen et al. 2009; Dallinger 1997; Frone et al. 1997; Grzywacz \& Marks 2000; Neal et al. 1997; Scharlach et al. 2007): (1) the impact of caregiving on employment and therefore indirectly on the carer's financial resources; (2) the impact of employment on caring; (3) the impact of the dual demands of working and caring on other family obligations and relationships; (4) the impact of working and caring on social life and leisure time; (5) the impact on the caregiver's health.

Most literature on reconciling employment and elderly care is concerned with only one dimension at a time and then mostly with the impact of care obligations on labour market participation. Many analyses show that there is a negative trade-off in terms of labour market participation if an employee takes on care responsibilities (Bolin et al. 2008; Crespo 2007; Heitmueller 2006; Reichert \& Naegele 1999; Schneider et al. 2001; Spiess \& Schneider 2003). Caregivers with intensive care responsibilities are more likely to reduce their working 
International Journal of Ageing and Later Life

time (Mutschler 1994; Sarasa 2008; Spiess \& Schneider 2003). There are gender and class differences in the degree of this negative impact. Women, especially if they cohabit with the person needing care, show a higher probability than men of reducing their paid working time (Arber \& Ginn 1995; Ettner 1995; Kramer \& Kipnis 1995; Pinquart \& Sörensen 2006; Sarkisian \& Gerstel 2004). Gender differences are the consequence of normative frameworks and the gendered division of labour, which assigns women the caring role (Fine \& Glendinning 2005; Gerstel \& Gallagher 1994) and therefore lowers the average opportunity costs of wives, as opposed to husbands, for leaving or reducing paid work.

Employees with lower income, lower education or lower occupational status are more likely to take on care obligations and face higher risks of labour market attrition (Bolin et al. 2008; Crespo 2007; Henz 2006; Viitanen 2005). The combination in working-class families of weaker financial resources (and thus fewer options to purchase care services) with geographically closer family networks largely explains the different impact of caregiving on employment in diverse social classes (Couch et al. 1999; Henz 2006; Johnson \& Lo Sasso 2000).

Caring for a parent not only involves "hands-on care". It may include also what Rosenthal et al. (2007) have called managerial care: carerelated discussions and planning with other family members or the care recipient about the care arrangement and financial matters, negotiation with and supervision of formal and informal, paid and unpaid care providers, carrying out relevant paperwork and seeking information. It is worth noting that the use of formal services and the awareness of entitlement to them require this specific kind of work and competence on the part of family carers. Based on a Canadian sample, Rosenthal et al. (2007) found that providing managerial care generates stress among women and interferes with work among men. The aspect that creates the greatest personal and job costs among both men and women is the organisation of care rather than financial or bureaucratic management.

The role of social policies has been addressed by numerous national and comparative studies, either from the point of view of the dependent person's entitlement to care (e.g. Doyle \& Timonen 2008; Pacolet et al. 2000) or with respect to their impact on and interaction with 
family and informal care (e.g. Anttonen et al. 2003; Arntz \& Thomsen 2008; Jegermalm 2005; Lewis 1998; Rostgaard 2002; Theobald 2008). More recently, some authors have suggested analysing care policies for the elderly (as well as for children) along the familialisationdefamilialisation continuum, distinguishing between defamilialisation, supported familialism and familialism by default, in order to understand the role that policies implicitly or explicitly assign to family solidarity in providing care (Leitner 2003; Rauch 2007; Saraceno 2010). This distinction appears particularly useful for understanding why different patterns of family care emerge in different countries (e.g. Sarasa \& Mestres 2007). It can also help us to understand whether policies alleviate or perpetuate social inequalities among both caredependent persons and family carers. A recent study by Sarasa and Billingsley (2008), based on comparative survey data, offers important insights on this issue. These authors found that both the parents' and the children's low-economic status are correlated with a higher provision of care by children, no matter the welfare regime (also see Groenou et al. 2006). This study also supported the "paradox of redistribution" articulated by Korpi and Palme (1998), which states that universal benefits counteract social inequalities better than meanstested benefits targeted at those with insufficient income. Thus, in countries that are more generous and universal in providing care, social inequalities are weaker among both care-dependent persons and caregivers. By contrast, where a large share of care needs is left to individual and family resources (familialism by default), female adult children in the lower classes, in particular, find themselves in tighter trade-offs between working and caring (Saraceno 2010). These trade-offs are not the same for men and women, given their different positions in the labour market. They are also not the same for all women. Women with limited economic means have fewer options than women with higher incomes, who can purchase part of the care work. These differences across social classes are particularly acute in countries with little public provision of services. But they are also present in countries where support takes the form of financial transfers (Ungerson \& Yeandle 2007), i.e. through supported familialism. In the latter situation, in fact, low-income women may face difficult trade-offs between staying 
International Journal of Ageing and Later Life

in a poorly paid job and paying for a care service, keeping the money for the family budget and caring full time, or keeping the money for the family budget while juggling care and job obligations. The German case is important in this respect because long-term care insurance, while leaving a large degree of care to individual and family resources (familialism by default), also offers a choice between service provision or cash benefits, i.e. between defamilialisation and supported familialism, for the quota of care it supports.

In this article, our specific aim is to understand whether and how this particular form of policy provision affects the options and strategies of adult children in employment who have care responsibilities, while also looking at interactions with gender and social class differences, as well as with specific family arrangements and cultures.

\section{German Long-Term Care Insurance}

German long-term care insurance, which was introduced in 1995, shoulders the basic care expenses for individuals with substantial care needs. Benefits are differentiated on the basis of level of dependency, which is precisely defined in terms of inability to perform necessary daily activities according to ADL criteria. In line with the principle of subsidiarity, primary care responsibility is left to the family and statutory long-term care insurance is not intended to cover all care needs. Furthermore, beneficiaries can choose between receiving the care allowance in cash or in kind, i.e. home care, attendance at daycare centres or residence in nursing homes. It is also possible to combine cash and in-kind benefits. Care allowances are graded on the basis of both the level of need and the type of care provision chosen. The monetary value of nursing-home care is the highest, while that of cash benefits is the lowest; the latter amounts to around one third of the value of nursing-home care and to half of that of home-based services. Since allowances do not cover the full amount of required care, care-dependent persons in nursing homes must pay almost half of the overall costs themselves. For the poor, social assistance may cover part of the additional costs. The allowance granted for home care is sufficient to finance between two and three half-hour visits per day 
by a care service. But this does not cover the caring time acknowledged as necessary for the different care levels (Pflegestufen). ${ }^{2}$ Additional time may be bought privately from the same services, purchased on the (cheaper) informal labour market or provided by family members. The system of long-term care insurance thus both expects a large amount of care to be performed by family providers, and at the same time de facto encourages recourse to irregular and cheap labour provided mostly by migrants (Kondratowitz 2005; Ostner 1998).

Main family carers who provide more than $14 \mathrm{~h}$ a week of care according to the criteria used for service provision - and are not, or are only part-time employed, may be assigned the status of "carer" (Pflegeperson). This status entitles them to old-age pension contributions and to insurance against accidents that may occur while providing care. Main family carers, subject to the agreement of the care-dependent person, may also request respite care (Kurzzeitpflege) and nursing-home care in cases of emergency (Verhinderungspflege) for a total of up to eight weeks per year.

Until the reform of long-term care insurance in June 2008, family carers in paid work had no statutory entitlement to days off from work for care obligations. Since the reform, caregivers are entitled to unpaid leave of maximum 6 months per person cared for. They also have the right to 10 days unpaid leave per year. Apart from this new statutory regulation, some collective and company agreements (particularly in large enterprises) include some kind of working-time allowance or flexibility for informal carers in employment (Dilger et al. 2007; Klammer \& Letablier 2007; Klenner 2005; Reichert \& Naegele 1999). However, both these agreements and the new statutory entitlement exclude small firms (the 2008 reform applies only to companies with over 15 employees) and thus a substantial share of carers.

Given this institutional framework, the receipt of adequate care depends to a large extent on the availability of both family carers and money. Care arrangements, even given public support, are strongly shaped by the

\footnotetext{
${ }^{2}$ The following amounts of care are recognised as necessary for the different care levels: level I, minimum 90 min daily; level II, minimum 3 h daily; level III, minimum $5 \mathrm{~h}$ daily.
} 
International Journal of Ageing and Later Life

financial status of the households and family networks involved, by the numerical size of these networks, by their gender composition and by the individual biographies of their members - i.e. by their often gender-specific "moral careers" (Dallinger 1997; Finch \& Mason 1993; Heusinger \& Klünder 2005).

\section{The Qualitative Study \\ Sampling Strategy and Sample Characteristics}

The sample consists of 34 individuals who work for pay at least $20 \mathrm{~h}$ per week and who are the main family carers for their parent(s) or parent(s)in-law. In order to be identified as main carer, the respondent had to bear the main responsibility for the overall care arrangements, either providing the main bulk of care directly or organising and supervising the "care package". In order to be defined as "dependent", a person had to need support in (instrumental) activities of daily living (IADL, ADL) and/or to be supervised for several hours a day. The sample, therefore, includes only persons with considerable obligations towards both care and paid work. Although the sample intentionally does not include those carers who, because of their care obligations, had to leave work, we do have three cases in which this happened shortly before the interview. We aimed at having a reasonably diversified sample with regard to income, professional status, family circumstances and extent of care needs.

The interviews were carried out in (East and West) Berlin and in the (mostly rural) Brandenburg region. Respondents were contacted through services and informal networks. The former route was prevalent in Berlin, the latter in Brandenburg, due to the different types of collaboration offered by the services in the two territories. This differential recruitment affected the characteristics of the respondents in the two contexts and particularly the incidence of their use of services, which was much higher in the Berlin subsample than in the Brandenburg one. The latter also comprises more families with lower incomes. In the following analysis, we will not use the geographical distinction, considering only the overall financial situation of carers.

Our sample includes only five men, compared to 29 women (see Table 1). The expected difficulty in finding men who are the main carers, due to their 
Caring for a parent while working in the German welfare regime

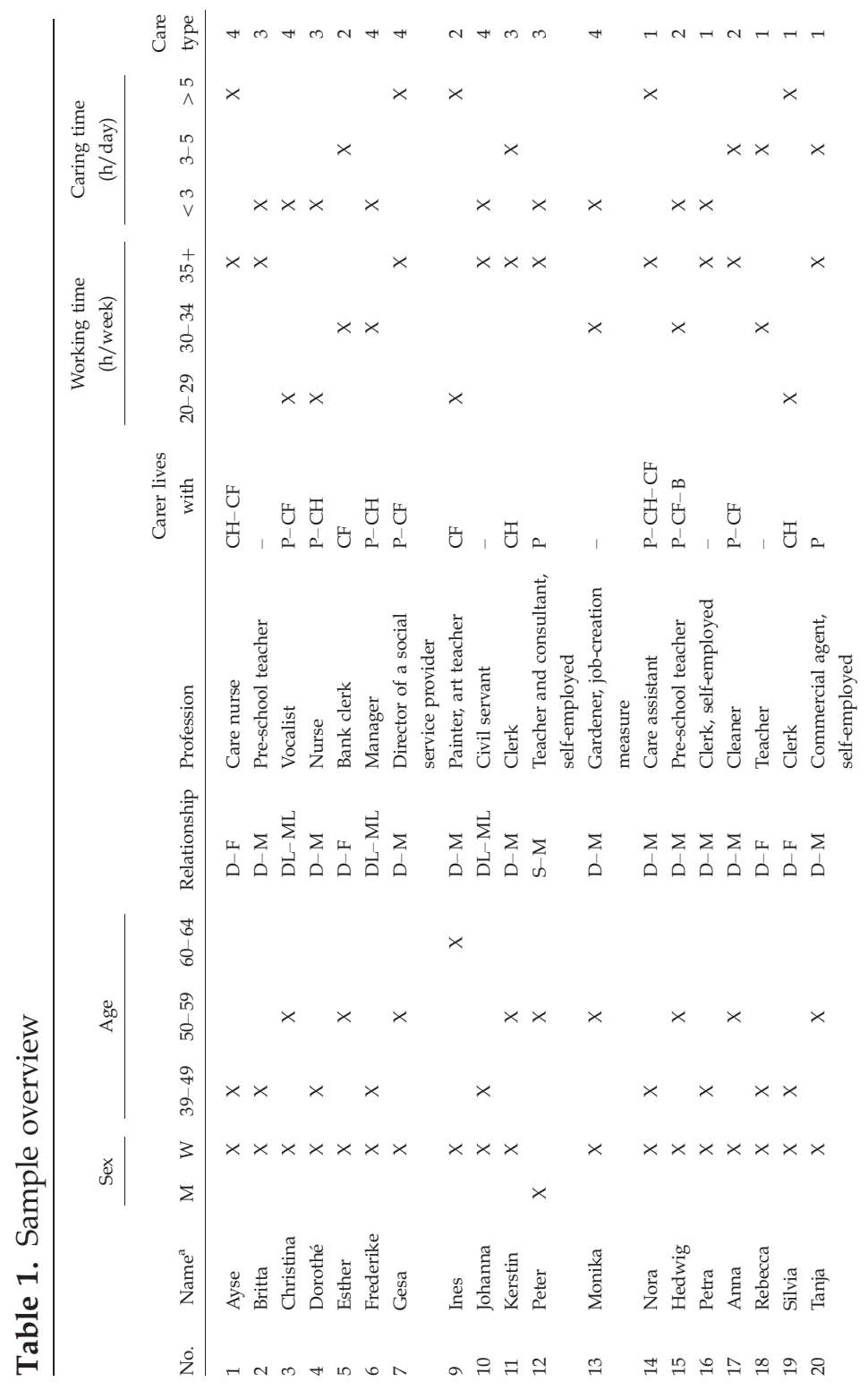


International Journal of Ageing and Later Life

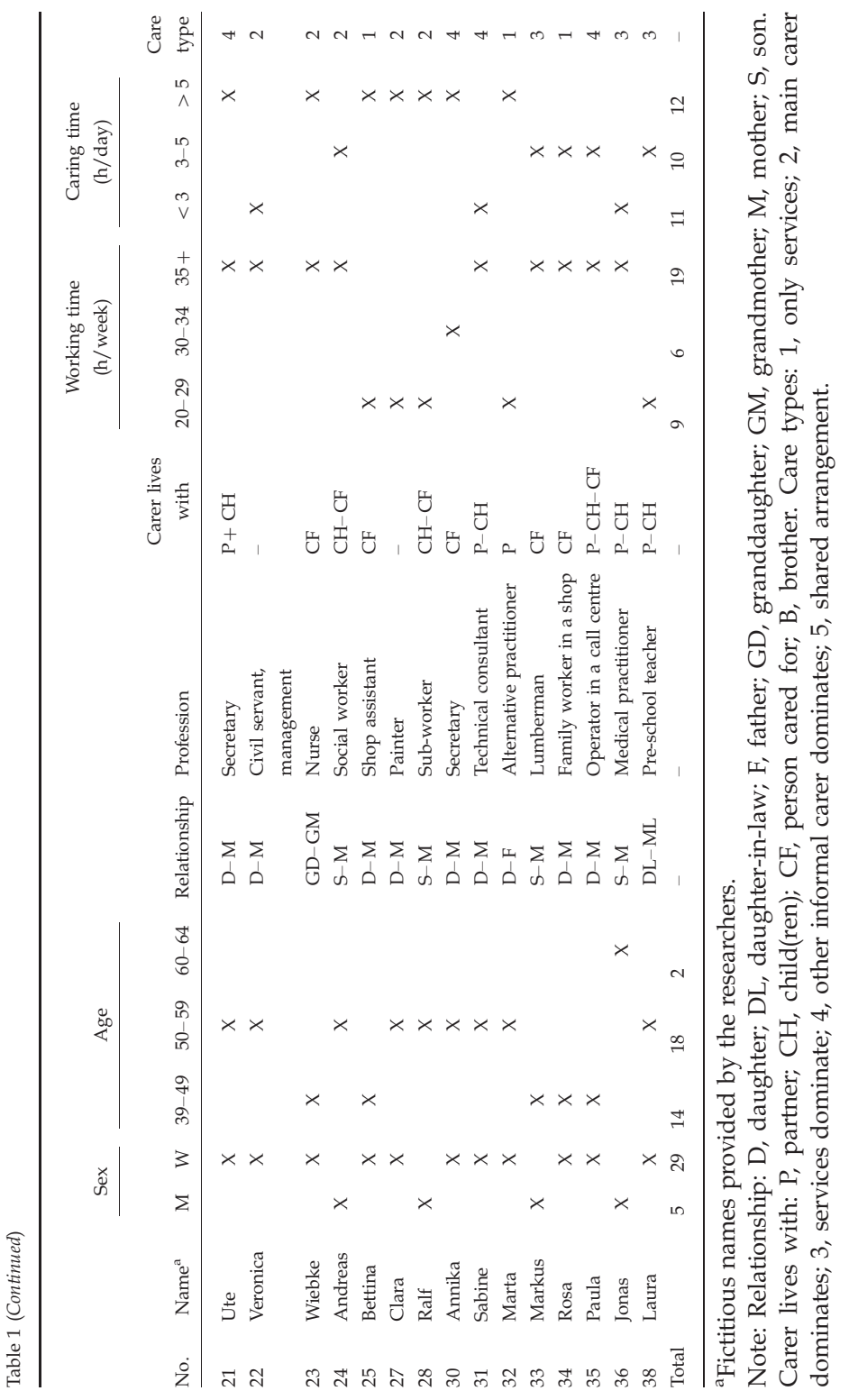


comparatively small number among children who care (see Kramer \& Thompson 2005; Schneekloth 2005), was compounded by the refusal of some men to be interviewed. There are, however, at least three male partners and two brothers who, although they were not interviewed, contribute at least as much care work as their spouses or sisters. And other husbands and brothers also offer substantial help, even if they do not share the care work equally. The presence of caring men in our sample is therefore broader than only those who were interviewed directly.

The daughter-mother relationship is prevalent - accounting for over half of all relationships - as also found in representative surveys (e.g. Schneekloth 2005). Some women are responsible for the care of their father- or mother-in-law. All five men care for their mothers.

A total of 14 of the persons cared for live in the same household as the carer. This arrangement is usually found in the low-income group and in the care arrangements with fewer non-family resources. Except for two cases, all the persons cared for are classified according to the three possible care levels (Pflegestufen), i.e. they are recognised as needing special care. Almost a quarter of our sample involves carers belonging to the so-called "sandwich generation" - people who have an additional care responsibilities towards minor children aged between 9 and 17 years.

At 19, the number of carers without a cohabiting partner is quite high; 13 of these are divorced. These are often the carers with the fewest options: they cannot opt out of the labour force because theirs is the only income available; at the same time, there are fewer people within the household with whom they can share the care responsibility.

Working time ranges from 20 to $80 \mathrm{~h}$ a week. Of the respondents, 19 work full time; six work extended part time of 30-34 h per week; and nine work less than $30 \mathrm{~h}$ per week. This distribution is similar to that found in two nationally representative surveys on family carers - the 2002 Infratest survey and the 2005 Mikrozensus. The weekly distribution of working time ranges from fixed, regular working time to shift work, flextime and work on demand. The occupational status of respondents ranges from executive and managerial positions to skilled manual work.

Among those who work full time, 12 provide care for more than $5 \mathrm{~h}$ a day. Caring time is high for most of the respondents: 22 provide care for 
International Journal of Ageing and Later Life

over $3 \mathrm{~h}$ a day, while 11 provide care for less than $3 \mathrm{~h}$ a day. Only in two cases are both paid working and caring time significantly lower. Most of the carers in the sample therefore have a high paid and unpaid workload.

In 12 cases, both the person cared for and the household of the caregiver are in a low-income bracket of less than $1300 €$ per month. ${ }^{3}$ In five cases, the carer and the person cared for have considerable income resources. In seven cases, the income of the person cared for is very low, whereas the household of the caregiver has at least moderate income resources. Unfortunately, not all respondents provided information on income, but we were able to estimate the material living standard of the carer on the basis of other information.

\section{Method and Analysis}

The interviews were semi-structured. For purposes of cross-national comparison, a common template was used in all countries, which touched on organisational features, the development of the care arrangement and its financial cost, the quality of the relationship with the person cared for and with other family members, the family-to-work and work-to-family tensions and conflicts, and the attitudes towards caring and towards work. The interviews were mostly carried out in the carer's home and lasted $2^{1 / 2} \mathrm{~h}$ on average. They were recorded and transcribed in full by the interviewer herself and were then coded with Atlas.ti. Content analysis was carried out independently by the two main researchers and then crosschecked. The analysis was aimed at (a) identifying modes of organisation of work/care arrangements, (b) detecting points and patterns of care-work tensions at the workplace, in the care relationship and in family relations and (c) identifying the resources and strategies used to deal with these tensions. The analysis concerned two distinct levels: that of factual circumstances and that of perceptions and feelings.

In this article, we focus on (a) the different care arrangements developed at the intersection of human and financial resources, paid work demands and form of public support and (b) the perceived tensions at the work-care interface and in relation to other, particularly family, relationships.

\footnotetext{
${ }^{3}$ Household income is weighted by the square root of the number of household members.
} 


\section{Patterns of Care and Work Arrangements}

Caring for an older frail person is almost always a combination and a collaboration between different, both informal and formal, caregivers (Anttonen et al. 2003; Lewis 1998), particularly when the main carer is also in work. Specific care arrangements are a product of varying restrictions and opportunities. Together with level and kind of dependency, a crucial role is played by size and availability of the family network, other family responsibilities, hours of work and, last but not least, the preferences of the person being cared for. In the German context, an important role is also played by the opportunities and constraints offered and imposed by long-term care insurance. Important factors are whether or not the care-dependent person is entitled to the insurance and the form in which the care allowance is taken. As we saw above, all but two of the caredependent persons receive the allowance. Most of them (and/or their carers) opt for receiving it at least partly in the form of services, which is more than that found in a nationally representative sample (Schneekloth 2005) which, however, included both working and non-working carers. Furthermore, in 12 cases, the statutory service provision is topped up by extensive use of day-care centres financed either by private means (usually the care-dependent person's pension) or, in the case of low-income earners, by social assistance. In the two cases in which there is no statutory care allowance, the main carer hires professional help. In no case is the respondent the only care provider. In addition to, or instead of services, other family members, particularly within his or her own household, often help the main caregiver. More rarely, friends or neighbours may help out.

Four different combinations of formal and informal support may be detected depending on the relative weight (in terms of time covered) of one of the components: (a) arrangement with no use of services, (b) mixed arrangement where the main family carer and her household prevail, (c) mixed arrangement where services prevail and (d) shared arrangement with a balanced contribution by various carers. The first two arrangements include only low-income households. The other two are more heterogeneous, although there is a prevalence of better-off households.

In the no service pattern (eight cases, all women), four carers work part time and four full time. The decision not to use services is in at least two cases explicitly motivated by budget constraints. 
International Journal of Ageing and Later Life

Bettina, a science PhD, had to relinquish a possible career in her chosen field and work instead as a part-time shop assistant due to a series of care obligations over time - first her father, now her mother. She lives in a small town in Brandenburg with her mother, who has been assigned Pflegestufe 2. Their overall budget amounts to $2300 €$ per month, of which 1000 are her mother's pension, 400 the care allowance and 200 the allowance Bettina receives as a Pflegeperson. She acknowledges that her mother would be better off if she could attend a day-care centre, but their household cannot afford to give up the care money. Bettina therefore performs most of the required care herself, with the help of two siblings.

Both of Silvia's parents are care-dependent and each of them lives with a different child. The two siblings also help each other with the care of the other parent, although it is the (18-year old) son who seems to bear the greater responsibility overall, at least while Silvia was working. She lost her job as an office clerk shortly before the interview because of her care responsibilities.

Financial issues are not always the main reason for not using services, however. A lack of trust in "strangers", a sense of duty or a desire for selfsufficiency may play a role, although we found this latter motivation only among low-income households. Tanja, for instance, lives in a rural context in Brandenburg with her mother, who suffers from dementia and has been assigned Pflegestufe 1. The mother refuses contact with anyone other than Tanja and Tanja's retired husband.

In the case of Nora's mother (Pflegestufe 2), "not wanting strangers" seems to be a view shared by both the dependent mother and her carers:

Because there are enough of us and we can manage it, and because we do not want to have a care service here. My mother doesn't want strangers in the house. (Nora)

The mixed arrangements where the main carer and her or his household prevail comprises 10 cases, two men and eight women. In two cases (a woman and a man), which are also among the poorest, the carer lives with the dependent parent and shares the household budget. Support from other family members is available but moderate. Irrespective of the level of dependency and of working hours, there is only a minimal use of formal or informal services. In this group, four carers work full time, five part time and one - Andreas, a former social worker - became unemployed shortly 
before the interview because of his care obligations. Until now, however, this man has refused to have his mother, with onsetting Alzheimer's disease, assessed under long-term care insurance. He previously had a negative experience with his father who, in Andreas' opinion, lost his autonomy because of over-caring:

\footnotetext{
She should be kept grounded. She's not a case for nursing care. She should stand her ground (emphasis). She does the dishes and organises the household, has her kind of work. It's important that she has something to do.
}

Divorced and living with his mother, Andreas performs most of the caring required, with some help from relatives and neighbours (whom he also partly pays) and from a private nurse his mother knows as a friend. He currently lives on his mother's pension and his unemployment benefit.

Esther moved to her father's house when he developed dementia. She is single and works extended part-time hours. For her, reducing working time is not an option. She needs an income to make a living and to build up her pension entitlement. She has no siblings and therefore has to manage the care arrangement on her own. During her working hours, her father is in a day-care centre. The cost for the care almost entirely uses up her father's pension. Because of her father's worsening dementia, she spends most of her free time with him, with little time for any social life.

In two cases belonging to this type of arrangement, we suspect that another person in the household has at least as much care responsibility as the self-defined main carer. In both cases, it is a husband, who however refused to be interviewed.

Hedwig does not fully use the care allowance in the form of services, since the household needs the money to round up the budget, given her husband's unemployment and her low wages as a childcare worker. She can count on her husband, who stays with Hedwig's bedridden mother (Pflegestufe 2) and feeds her lunch while Hedwig is at work. The home-care service provides basic body care and some mobility exercises. But most of the care work is performed by Hedwig and her husband. Anna's case is similar.

In the mixed arrangements where services dominate (seven cases: two men and five women), the majority (five) of carers work full time. Either they or the person cared for generally has a comfortable income, and in no case 
International Journal of Ageing and Later Life

are there serious budget constraints. In all cases, the dependent parent (Pflegestufe 1 or 2) attends a day-care centre 5 days a week. If necessary, he or she is brought there and back by a driving service and in some cases also receives home visits for body care. In all cases, the cost of these services is only partly covered by the care allowance and is topped up to the tune of between 130 and $700 €$ per month by the old person's personal income. The main family carer generally has the role of care manager, in addition to being present in the evening and at the weekends.

Britta's mother, for instance, has been assigned Pflegestufe 2 and for many years used both home- and day-care services as well as meals on wheels while living on her own. Shortly before the interview, she had to move to a residential home because of deterioration in her condition. Before this move, Britta visited for over $2 \mathrm{~h}$ a day and at weekends (something she keeps doing now, although in a more relaxed way) and answered emergency calls at night. Some neighbours were available for small chores and Britta's daughter might be called upon if Britta were ill. Peter, who has recently taken over the main care responsibility for his mother from his wife, due to the poor relationship between the two women, also acts de facto mainly as the manager of a care arrangement where he calls on services to perform most of the daily tasks.

In the shared arrangements (ten cases), caring is divided between the main carer, services and other family members or friends. All but one carer in this group work either full time or extended part time and two are freelance artists. As in the previous type of arrangement, we find both high-income households and modest- to low-income situations.

Compared to the other arrangements, this last usually provides a higher degree of overall caring time coverage. Home care services, day-care services and in some cases also home help are used for a substantial amount of time every day. And more than one family carer is present on a regular basis when services are not available. Only in two cases is the cost of services fully covered by the care allowance. In the remaining cases, the shortfall is paid out of the dependent person's pension. In one case, no formal service is used, but a privately hired carer is paid out of the cash allowance.

Ayse lives with her old dependent father and 11-year-old son. She works full time as a nurse in an out-patient nursing service. Her father (Pflegestufe 
2) is in a day-care centre every weekday from 7.30 a.m. until 4 p.m., with someone driving him there and back. Her 11-year-old son stays with his grandfather until she comes home from work. Her brother and his wife also help.

Christina and Michael - both self-employed - care for his mother together, who has dementia (Pflegestufe 2) and lives by herself. The woman attends a day-care centre 5 days a week and a home-care service visits her twice a day. The couple visits her every day, does the shopping, takes her to the doctor and so forth. This arrangement is very expensive and only a third is covered by the care allowance, the remaining by the old woman's pension.

Jonas, a medical doctor, shared the daily care of his mother with his sister-in-law and his brother, until the mother, who was first allocated Pflegestufe 2 and then Pflegestufe 3, died shortly before the interview. Most of the "hands-on" care tasks, however, were performed by the home-care service, the statutory time of which was extended by means of extra payments.

Frederike is a manager who works part time. Her mother-in-law, who died recently, had terminal cancer and lived with a son in a city $35 \mathrm{~km}$ away. Home-care services provided most of the body and medical care three times a day; a cleaning woman performed most of the housework. But, for the hour-to-hour care ...

\footnotetext{
We decided on the care arrangement as a family. Basically five to six people provided care. My brother-in-law, who lives in the house, provided massive support during the evening and night, of course. Apart from that, we organised fixed care days so that everyone could deal adequately with his or her private life and childcare responsibilities.
}

The exception to the generally high time coverage offered by this shared arrangement pattern is that of Monika, whose mother has not yet been allocated a Pflegestufe. Monika is unemployed and receives social assistance. In exchange, she works in a so-called "one euro job" and also attends training courses towards obtaining a "real job". Her sister, a medical doctor, offers very limited help. The mother attends a day-care centre one day a week, which is paid out of her pension. For the remaining time, she is either by herself or with Monika, who strongly resists being 
International Journal of Ageing and Later Life

too involved, since she perceives it as unfair and has a difficult relationship with her mother.

All these different arrangements were more or less stable at the time of the interview, but they were always the result of progressive adjustments and in some cases also of radical changes over time. The carers perceived them as needing constant rearrangement and close monitoring, either because of the uncertainty of the arrangement, or because a change in the situation was anticipated. Worsening of the dependency conditions or failure of some part of the arrangement are ever-present risks. In our sample, such cases are frequent and create a feeling in many carers of always living in some kind of emergency and of not being able to plan beyond the day-to-day perspective.

\section{Multiple Interferences}

All of our carers experience problems of conciliation in the five dimensions suggested as relevant in the literature. But their incidence and intensity vary depending on the care arrangement, the situation at work and the overall family situation.

\section{Care-to-Work Interferences}

At least three carers (two women and one man) eventually had to leave their job or were fired. Others had to substantially reduce their working time. Many had to forego a career. Six women carers do not work in the field they are trained for and four accepted a position with a lower qualification level because of care responsibilities.

Negotiations with employers and supervisors over working schedules are frequent and sometimes conflictual, particularly among the lowerincome workers and when the care arrangement is based exclusively, or mainly, on the carer's resources and time (Types 1 and 2). Bettina, who cares for her mother with only some help from siblings, says that she worries:

Well, the whole time. Is everything OK? Has she fallen? Has she burned herself? Is she doing something she shouldn't do or has she forgotten to turn the cooker off? I get into trouble because she calls me at work, for example, because something has happened. My supervisor doesn't like this, of course. 
Tanja (Type 1), who works as a commercial agent for an insurance company on a self-employed basis, had to forego participating in further training, thus weakening her position in the company:

I reduce it [attending on-the-job training] and I do have problems in the company, because they do not accept it, someone not participating in their seminars; but there is no advantage for me at all, whether they accept it or not. That's the energy I have, and I have to manage it so that something is left for everyone.

Fear of losing her job because her employer will not accept her care responsibilities is so strong for Anna (Type 2), who works full time as a cleaner, that she has not informed her boss and colleagues about her situation. She organises her caring around her work schedule, counting on the fact that her husband is currently unemployed and thus can stay at home when she is at work.

For those with more secure job positions and more balanced care arrangements, the issue is rather one of boundary setting and keeping an overall balance. Johanna, who works full time in a public administration and whose arrangement belongs to Type 4, says:

I could work overtime, but I don't because I wouldn't be able to cope with everything. I just get by with my tasks so that I have a more or less balanced working-time account at the end of the month. I wouldn't be able to work more.

Somebody has reduced own working time and consequently also own income. Ralf (Type 2), a carpenter, halved his working time when he began caring for his mother, with whom he now shares the household budget. A similar decision was taken by Bettina (Type 1). From a more favourable position, Christina, a former researcher and now a freelance artist who lives with her husband (Type 4), re-invented a part-time career for herself in order to be able to care for her mother-in-law. In some cases, however, as in that of Annika (Type 4), reducing working time may lead to being fired. In others, it might hamper career prospects. Esther (Type 2), who works reduced hours because of caring for her father, reports that, although de jure job offers do not exclude part-time workers, de facto applicants in her company who are willing to work full time are always preferred over parttime employees. 
International Journal of Ageing and Later Life

Self-employed workers, notwithstanding their apparently flexible schedules and autonomy, sometimes have more problems than waged workers because they cannot afford not to meet their clients' demands.

Tension and overburdening may also result in health problems, which in turn affect working time. One of our respondents had a sudden breakdown because of lack of sleep and had to stay at home for a long period. Others stated that they have increased the number of sick days they take. These situations are more frequent when carers have the main responsibility for the "hands-on", physically arduous body care and when no home-care service is provided (Types 1 and partly 2).

Notwithstanding these difficulties, for most respondents, quitting work even only temporarily - is however unthinkable, for financial, strategic and in many cases identity reasons. The latter is, for instance, the case for Gesa, a director of a social service provider, who cares for her mother in a shared arrangement pattern:

I have to say it frankly. For me it is very important [to work]. At work I focus on my job, that is my field and I have my private life. There is no [caring], it is not present. And for me it is very important while I am here ... not to be involved there [in caring] in any way. I did not do it [leave work] for my children, because being at work is mine, it belongs to me. (laughs)

A similar view is expressed by Dorothé (Type 3):

Caring for my mother at home, that is too one-sided. There [at work] you have other things on your mind, you do something different and there are challenges, mentally. You cannot be immersed always in your own life. And you recognise that there are other people who are also not doing so well.

\section{Work-to-Care Interferences}

Working responsibilities may also interfere negatively with caring, particularly when the care arrangement does not provide sufficient time coverage. This occurs more often in the first two types of arrangement, where the bulk of care is mostly on the carer's shoulders. In one case, Wiebke (Type 2), the carer puts the dependent person - who is unable to move independently back to bed after breakfast, leaving her unattended and unable to move until the early afternoon when Wiebke comes back from work. A similar case is 
that of Tanja's mother (Type 1), who lives by herself, has dementia and some mobility problems, but does not want any strangers around her. Tanja worries:

It would be nice if somebody were always there, but that is simply not possible. It is too time-consuming. You always have to organise things so that she [mother] has something to do. If nobody is around and she is alone at home and the sun is shining, then she'll go outside, she'll do that. Then something stupid happens. She goes upstairs, falls down and so on ... In fact, somebody should be with her.

Silvia (Type 1), who relies only on informal help, complains that outside her care duties she has no time to actually spend with her father, to take him out occasionally:

When? We don't have the opportunity. We'd like to take him out in a wheelchair. (...) I ask myself, when summer comes, when might we do this? How and when?

Johanna (Type 4), whose mother-in-law attends a day-care centre twice a week and otherwise remains at home alone all day, worries that the woman sleeps too much out of sheer boredom.

Concern for the safety of the frail parent when left alone is also present in other, more complete, arrangements, as indicated by Ute's (Type 4) experience:

\footnotetext{
... it's more that I'm anxious - in the evenings. She [mother, with dementia] is brought back [from the day-care centre] at around $6 \mathrm{p} . \mathrm{m}$. and if I have pressure at work and realise that I'll be late ... I can leave her alone without a bad conscience for one or two hours maximum. But if it gets any longer, then I become nervous, because I'm afraid, because often something happens at home.
}

Carers with rigid work schedules complain more often than those with more flexible ones of conciliation problems, particularly if they do not have a support network to fall back on. If the caregivers have a job in which they are indispensable, they always have a fallback solution in which either services or another informal carer may step in and take over responsibility. In fact, not all our carers work under collective agreements that include special provisions for carers. And even if they do, they do not seem aware of this possibility, since nobody has ever mentioned it. The only instrument 
International Journal of Ageing and Later Life

they use, if it is contractually available, is working-time accounts, which give some flexibility in organising working time, but do not really offer "time off" to care.

Generally, negotiations in the workplace are informal, based on personal relationships rather than some kind of entitlement. Although most carers can develop this kind of informal negotiation, they also feel vulnerable because of it.

\section{Interference with Other Family Relationships and Obligations}

Conciliation problems may arise also on the family front, in relationships with partners and children. Children have to learn how to deal with the lack of time and divided loyalties of their parents. And the caring parent must also deal with these divided loyalties and conflicting expectations. In the experience of Hedwig, whose mother lives in the same household (Type 2):

You don't have so much time for each other [in the family] and my daughter always says: "We can never go on a trip because of grandma". And it's true, that's always the case.

Some of the children involved in our sample have been experiencing the care dependency of their grandparent(s) for a long time. This is the case for Cristina's 13- and 15-year-old children (Type 4), because first one, then another grandparent became dependent while the children were growing up. In at least four cases, children developed behavioural problems. Frederike (Type 4) recalls:

\footnotetext{
It [high time pressure] had an effect on my daughter. She shows a tendency to selfharm, because she is very sensitive. She started to cut her hair; then there was a period when she did not eat anything. Then she damaged my car with a stone (laughs) to attract attention to herself, because we didn't realise that we suddenly had very little time for her. And she suffers from the illness of her grandma and the experience of how she is deteriorating.
}

In this case, a high-intensity shared arrangement, the parents responded to the child's demands by reducing their caring time and dedicating more time to their daughter, and the situation improved. In other cases, however, parents acknowledge that there is a problem, but they do not have the time or other resources to deal with it. 
The experience of caring may also be enriching, however. Family ties are strengthened; children learn the meaning of intergenerational solidarity and also how to face the experience of ageing. Ayse (Type 4), for instance, is proud of her responsible young son. And Ralf (Type 2), speaking of his 11-year-old daughter, says:

It makes her understand concretely how it can be in old age. These things are actually not necessarily always nice experiences. But they are experiences that are important.

According to Wiebke (Type 2), the caring experience has strengthened the family bond:

\footnotetext{
It [family life] is becoming more intense. Grandma gives us more of a sense of family. I once had a relationship that broke up; afterwards it was a not really like a family anymore, especially for the children. But now that grandma is here, it is like a small, intact family circle. And the children enjoy it very much. Nina [17-year-old daughter] is always complaining when I say "Take the trash out!" or "Today you have to care for grandma!" But at the end of the day she does it and she also likes it. And the eldest [daughter], she's even more attached to grandma anyway.
}

Relationships with partners can be under stress because of care obligations. In at least one case, caring was the main cause of divorce. Due to her care obligations, Silvia (Type 1) not only lost her job, but also her husband, who wanted her to choose between him and her mother. In other cases, care obligations made it impossible to really develop a relationship. Bettina has started a relationship,

... but it is just difficult. You cannot really be away and you also cannot take her (mother) along. It limits the private time with friends and a partner a lot.

Wiebke (Type 2), who is 45 and cares for her grandmother while working at two jobs and studying medicine, comments:

I think, gosh, my prime years are passing by. You could look for a man. But there is no time at all.

Nonetheless, other respondents state that the experience may strengthen the couple or that only a solid couple can survive the stress caused by this 
International Journal of Ageing and Later Life

kind of obligation. Gesa (Type 4), for instance, speaking of her relationship, says:

We have had relationship problems. They were very evident. It [the care arrangement] is virtually a marriage in a threesome. But now we have climbed a high mountain and we are growing along with this situation.

And Anna (Type 2) emphatically declares:

But it can't work if one has a job and also has someone in need of care at home without having a partner at home to give support. It can't work, absolutely not.

\section{Interference with Leisure and Social Life}

Most carers, irrespective of their social status and care arrangement, have had to greatly reduce their leisure time and social activities. Weekends and holidays are often times in which services reduce their provision and the carer tries to "make up" for what she or he has not been able to do during the week. Dorothé (Type 3), who cares for her mother with Alzheimer's disease, explains:

It is maybe possible to travel for a long weekend, but not to go away for a trip for a week. We have not done this for the last three years. Well, I would have no peace in a sense.

Ute (Type 4) can count on day care every weekday as well as on her husband's help. But she must use up all her vacation time to take her mother to her routine medical checks twice every month.

A large majority of respondents say that they have lost friends who could not adjust to the rigidity of the carer's time schedule. And most carers have had to abandon formerly cherished activities. Those who cannot count on other family members or other informal help seem more exposed to this risk of a strong reduction in social life, because they have nobody to count on to share the burden, but also because they are isolated. 
Caring for a parent while working in the German welfare regime

\section{Conclusion: Tensions, Resources and the Role of Policies}

All our carers are under some kind of pressure on their time and on their loyalty. However, the points of major pressure and of perceived difficulty differ along the five dimensions identified in the literature. For some carers, the main concerns regard their job and care-to-work interference: how to deal with job demands, how to keep one's job, how to find a job after losing the previous one, given the care demands. For other carers, the main point of concern is the (in)adequacy of the care arrangement and the work-to-care interference. Particularly when the care-dependent person has to remain alone for many hours a day, the constant worry that something bad will happen never seems to leave the main caregiver. For others still, the main tensions concern neither the care nor the work arrangements. Perceived tensions instead regard the constraints that having both obligations put on the carer's private life: on the relationship with and welfare of children, partners and friends.

How these different concerns are distributed and experienced in the sample is not random. Degree of dependency (or rather autonomy) of the person cared for is, of course, the first important factor. A second element concerns the perceived adequacy of the care arrangement. Being supported by one's own household and extended family may reduce the feeling of isolation and/or conflict of loyalty. But family support may not be enough to ensure an adequate work-family-care balance. Access to non-family services and having the financial means to be able to buy adequate care greatly reduce family carers' caring time. They also reduce the constant worry about the security and welfare of the care-dependent person, while giving him or her the possibility to develop wider social contacts and to be monitored and supported in a professional way. Finally, the caredependent person's behaviour and reaction also play an important role in easing - or further increasing - the tensions inherent in all care arrangements where carers have multiple responsibilities, loyalties and interests. In this perspective, the cases involving mental disorder, like dementia, are the most difficult, because they often involve some kind of aggression or lack of acknowledgement, which may feed on previous histories of difficult relationships. 
International Journal of Ageing and Later Life

Social-care policies play an important, although not exclusive, role in the strategies carers may implement and in the kind of tensions and risks they experience as a result of their care responsibilities (Saraceno 2010; Sarasa 2008; Theobald 2008). In this perspective, the situations in our sample are good examples of the virtues, as well as the shortcomings, of German long-term care insurance. Once a person is acknowledged as having some kind of dependency, he or she, and indirectly his or her carers, may count on some form of support. But this support is limited and, in order to be adequate, it requires a large amount of integration by the family or privately paid services. Since all carers in the sample work for pay, the inadequacy of the care provided by long-term care insurance implies that either they work part time, or they must do a second (or a third, if they have their own family) shift, or must negotiate responsibilities and arrangements with other family members, or find the financial resources to buy extra help. If they lack family or financial resources, or if the caredependent person's pension is too low, they risk being overburdened to the point of having to leave their job - a risk that particularly concerns lowincome women. Or the care-dependent person risks not receiving all the care he or she needs - a risk that affects low-income dependent parents of low-income children.

In this perspective, one might argue that, contrary Korpi and Palme's (1998) thesis, universality is not enough to reduce social inequalities. Amount and adequacy of support also matter. Notwithstanding its universality in coverage, in fact German long-term care insurance does not succeed in reducing social-class inequalities - neither among the caredependent nor among their carers. It also confirms gender inequalities in so far as the availability to care, within families, is expected more from women. This failure is partly due to the excessively limited care support, thus to the resulting high degree of familialism by default, partly also to the "framework of choice" between partial defamilialisation through careservice provision and partially supported familialism through cash-for-care benefits. Income needs may, in fact, require taking the allowance in the form of money rather than services, or may force people to take only the basic amount of services allocated for free, in both cases increasing the risk both of overburdening and undercaring (see Backes 1998). In our sample, irrespective of the dependency level, only low-income households do not 
Caring for a parent while working in the German welfare regime

use any services at all. At the opposite end, the higher-income households (and the care-dependent persons with the highest pensions) exhibit the greatest use of statutory and privately paid services.

\section{Acknowledgements}

We thank our colleagues in the other national teams of the WOUPS project for useful discussions. We also thank Anita Fürstenberg, who organised and carried out all the interviews, and Philipp Hessel, who summarised them. The transcripts of the interviews and the codebook are stored at the WZB.

\section{Corresponding Author}

Chiara Saraceno, Wissenschaftszentrum Berlin für Sozialforschung (WZB), Reichpietschufer 50, 10785 Berlin, Germany. Email: saraceno@wzb.eu

\section{References}

Anttonen, A., Baldock, J. \& Sipilä, J. (eds.). (2003). The Young, The Old, and The State. Cheltenham: Edward Elgar.

Arber, S. \& Ginn, J. (1995). Gender differences in the relationship between paid employment and informal care. Work Employment and Society 9(3): 445-471.

Arntz, M. \& Thomsen, S. L. (2008). Crowding Out Informal Care? Evidence From a Social Experiment in Germany. Mannheim: Zentrum für Europäische Wirtschaftsforschung.

Backes, G. M. (1998). Zwischen Erwerbsarbeit und häuslicher Pflege Perspektiven der Vereinbarkeit für Frauen und Männer in Deutschland [Between Paid Work and Domestic Care - Perspectives on Conciliation for Women and Men in Germany]. In G. Naegele \& M. Reichert (eds.), Vereinbarkeit von Erwerbstätigkeit und Pflege [Reconciliation of Work and Care] (pp. 107-124). Hannover: Vincentz.

Blinkert, B. \& Klie, T. (2001). Zukünftige Entwicklungen des Verh “̈̈ltnisses von professioneller und häuslicher Pflege bei differierenden Arrangements und privaten Ressourcen bis zum Jahre 2050 [Future Developments of the Relationship between Professional and Domestic Care in Differing 
International Journal of Ageing and Later Life

Arrangements and Private Resources until the Year 2050]. Berlin: Enquete-Kommission Demographischer Wandel des Deutschen Bundestages.

Bolin, K., Lindgren, B. \& Lundborg, P. (2008). Your next in kind or your own career? Caring and working among the $50+$ in Europe. Journal of Health Economics 27(3): 718-738.

Couch, K. A., Daly, M. C. \& Wolf, D. A. (1999). Time? Money? Both? The allocation of resources to older parents. Demography 39(2): 219-232.

Crespo, L. (2007). Caring for Parents and Employment Status of European MidLife Women. Madrid: Centro de Estudios Monetarios y Financieros (CEMFI).

Cullen, J. C., Hammer, L. B., Neal, M. B. \& Sinclair, R. R. (2009). Development of a typology of dual-earner couples caring for children and aging parents. Journal of Family Issues 30(4): 458-483.

Dallinger, U. (1997). Ökonomie der Moral. Konflikt zwischen familiärer Pflege und Beruf aus handlungstheoretischer Perspektive [Moral Economy. Conflict Between Familial Care and Occupation from the Perspective of Action Theory]. Opladen: Westdeutscher Verlag.

Dilger, A., Gerlach, I. \& Schneider, H. (2007). Betriebliche Familienpolitik [Family Policy in Companies]. Wiesbaden: VS Verlag für Sozialwissenschaften.

Doyle, M. \& Timonen, V. (eds.). (2008). Home Care for Ageing Populations. Cheltenham: Edward Elgar.

Ettner, S. L. (1995). The impact of parent care on female labor supply decisions. Demography 32(1): 63-80.

Finch, J. \& Mason, J. (1993). Negotiating Family Obligations. London: Routledge.

Fine, M. \& Glendinning, C. (2005). Dependence, independence or interdependence? Revisiting the concepts of "care" and "dependency". Ageing and Society 25(4): 601-621.

Frone, M. R., Yardley, J. K. \& Markel, K. S. (1997). Developing and testing an integrative model of the work-family interface. Journal of Vocational Behavior 50(2): 145-167.

Gerstel, N. \& Gallagher, S. (1994). Caring for kith and kin: Gender, employment, and the privatization of care. Social Problems 41(4): 519-538. 
Groenou, M. B. van, Glaser, K., Tomassini, C. \& Jacobs, T. (2006). Socioeconomic status differences in older people's use of informal and formal help: A comparison of four countries. Ageing \& Society 26(5): 745-766.

Grzywacz, J. G. \& Marks, N. F. (2000). Reconceptualizing the work-family interface: An ecological perspective on the correlates of positive and negative spillover between work and family. Journal of Occupational Health Psychology 5(1): 111-126.

Häcker, J. \& Raffelhüschen, B. (2007). Zukünftige Pflege ohne Familie: Konsequenzen des "Heimsog-Effekts" [Future care without family: Consequences of the hospitalisation trend]. Zeitschrift für Sozialreform 53(4): 391-422.

Heitmueller, A. (2006). The chicken or the egg? Endogeneity in labour market participation of informal carers in England. Journal of Health Economics 26(3): 536-559.

Henz, U. (2006). Informal caregiving at working age: Effects of job characteristics and family configuration. Journal of Marriage and Family 68(2): 411-429.

Heusinger, J. \& Klünder, M. (2005). "Ich lass' mir nicht die Butter vom Brot nehmen". Aushandlungsprozesse in häuslichen Pflegearrangements ["I Won't Let Them Take What's Mine". Processes of Negotiation in Domestic Care Arrangements]. Frankfurt: Marbuse.

Jegermalm, M. (2005). Carers in the Welfare State. Stockholm: Stockholm University Press.

Johnson, R. W. \& Lo Sasso, A. T. (2000). The Trade-Offbetween Hours of Paid Employment and Time Assistance to Elderly Parents at Mid-Life. Washington, DC: The Urban Institute.

Klammer, U. \& Letablier, M-T. (2007). Family policies in Germany and France: The role of social partners and enterprises. Social Policy \& Administration 41(6): 672-692.

Klenner, C. (2005). Gleichstellung von Frauen und Männern und Vereinbarkeit von Familie und Beruf-Eine Analyse von tariflichen Regelungen in ausgewählten Tarifbereichen [Equality between Men and Women and Work-Family Conciliation. An Analysis of Wage Regulations in selected contractual Sectors]. In H-B Stiftung (ed.), WSITarifhandbuch 2005 (pp. 41-65). Frankfurt: Bund Verlag. 
International Journal of Ageing and Later Life

Kondratowitz, H. J. von. (2005). Die Beschäftigung von Migranten/innen in der Pflege [Employment of migrants in the field of care]. Zeitschrift für Gerontologie und Geriatrie 38(6): 417-423.

Korpi, W. \& Palme, J. (1998). The paradox of redistribution and strategies of equality: Welfare state institutions, inequality, and poverty in the western countries. American Sociological Review 63(5): 661-687.

Kramer, B. J. \& Kipnis, S. (1995). Eldercare and work-role conflict: Toward an understanding of gender differences in caregiver burden. The Gerontologist 35(3): 340-348.

Kramer, B. J. \& Thompson, E. H. (2005). Men as Caregivers. New York: Prometheus Books.

Lechner, V. M. (1999). Final Thoughts. In V. M. Lechner \& M. B. Neal (eds.), Work and Caring for the Elderly. International Perspectives (pp. 211-228). Philadelphia, PA: Taylor and Francis.

Leitner, S. (2003). Varieties of familialism: The caring function of the family in comparative perspective. European Societies 5(4): 353-375.

Lewis, J. (ed.). (1998). Gender, Social Care and Welfare State Restructuring in Europe. London: Ashgate.

Mutschler, P. H. (1994). From executive suite to production line. Research on Aging 16(1): 7-26.

Neal, M. B., Ingersoll-Dayton, B. \& Starrels, M. E. (1997). Gender and relationship differences in caregiving patterns and consequences among employed caregivers. The Gerontologist 37(6): 804-816.

Ostner, I. (1998). The Politics of Care Policies in Germany. In J. Lewis (ed.), Gender, Social Care and Welfare State Restructuring in Europe (pp. 111138). Aldershot: Ashgate.

Pacolet, J., Bouton, R., Lanoye, H. \& Versieck, K. (2000). Social Protection for Dependency in Old Age: A Study of Fifteen EU Member States and Norway. Aldershot: Ashgate.

Parker, G. (1992). Counting Care: Numbers and Types of Informal Carers. In J. Twigg (ed.), Carers: Research and Practice (pp. 6-29). London: HMSO.

Pinquart, M. \& Sörensen, S. (2006). Gender differences in caregiver stressors, social resources, and health: An updated meta-analysis. Journal of Gerontology 61(1): 33-45. 
Rauch, D. (2007). Is there really a Scandinavian social service model? Acta Sociologica 50(3): 249-269.

Reichert, M. \& Naegele, G. (1999). Elder Care and the Workplace in Germany: An Issue or the Future. In V. M. Lechner \& M. B. Neal (eds.), Work and Caring for the Elderly. International Perspectives (pp. 29-46). Philadelphia, PA: Taylor and Francis.

Rosenthal, C. J., Martin-Mathews, A. \& Keefe, J. M. (2007). Care management and care provision for older relatives amongst employed informal care-givers. Ageing \& Society 27(3): 755-778.

Rostgaard, T. (2002). Caring for children and older people in Europe a comparison of European policies and practice. Policy Studies 23(1): $51-68$.

Saraceno, C. (2010). Social inequalities in facing old-age dependency: A bi-generational perspective. European Journal of Social Policy 20(1): 1-13.

Sarasa, S. (2008). Do welfare benefits affect women's choices of adult caregiving? European Sociological Review 24(1): 37-51.

Sarasa, S. \& Billingsley, S. (2008). Personal and Household Caregiving from Adult Children to Parents and Social Stratification. In C. Saraceno (ed.), Families, Ageing and Social Policy (pp. 123-146). Cheltenham: Edward Elgar.

Sarasa, S. \& Mestres, J. (2007). Women's Employment and the Adult Caring Burden. In G. Esping-Andersen (ed.), Family Formation and Family Dilemmas in Contemporary Europe (pp. 185-222). Bilbao: FBBVA.

Sarkisian, N. \& Gerstel, N. (2004). Explaining the gender gap in help to parents: The importance of employment. Journal of Marriage and Family 66(2): 431-451.

Scharlach, A. E., Gustavson, K. \& Dal Santo, T. S. (2007). Assistance received by employed caregivers and their care recipients: Who helps care recipients when caregivers work full time? The Gerontologist 47(6): $752-762$.

Schneekloth, U. (2005). Entwicklungstrends beim Hilfe- und Pflegebedarf in Privathaushalten: Ergebnisse der Infratest Repräsentativerhebung [Trends in the Need for Help and Care in Private Households: Results from the Infratest Sample Survey]. Munich: TNS Infratest Sozialforschung. 
International Journal of Ageing and Later Life

Schneider, T., Drobnic, S. \& Blossfeld, H-P. (2001). Pflegebedürftige Personen im Haushalt und das Erwerbsverhalten verheirateter Frauen [People in need of care within the household and employment behavior among married women]. Zeitschrift für Soziologie 30(5): 362-383.

Schupp, J. \& Künemund, H. (2004). Private Versorgung und Betreuung von Pflegebedürftigen in Deutschland [Private Care and Assistance for People in Need of Care in Germany]. Berlin: Deutsches Institut für Wirtschaftsforschung.

Spiess, C. K. \& Schneider, A. U. (2003). Interactions between care-giving and paid work hours among European midlife women, 1994 to 1996. Ageing \& Society 23(1): 41-68.

Theobald, H. (2008). Care-Politiken, Care-Arbeitsmarkt und Ungleichheit: Schweden, Deutschland und Italien im Vergleich [Care politics, care labour market and inequality: A comparison of Sweden, Germany and Italy]. Berliner Journal für Soziologie 18(2): 257-281.

Ungerson, C. \& Yeandle, S. (2007). Cash for Care Systems in Developed Welfare States. Basingstoke: Palgrave Macmillan.

Viitanen, T. K. (2005). Informal Elderly Care and Female Labour Force Participation across Europe. ENEPRI Research Report No. 13. 